\title{
W9-4
}

\section{ベーチェット病ぶどう膜炎モデル動物を用いた制御性 $\mathbf{T}$ 細胞による炎症抑制機構}

\section{慶野 博}

\section{（杏林大学医学部 眼科学教室）}

ベーチェット病は難治性ぶどう膜網膜炎, 口内炎, 陰部潰瘍, 皮膚症状を呈する全身性炎症性疾患で ある，原因は未だ不明であるが，ベーチェット病の病態に好中球の機能充進や Streptococcus Sanguinis などの連鎖球菌に対する過剰な免疫応答が関与していることが推測されている．また最近の GWAS 解 析からべーチェット病の疾患感受性遺伝子として IL-12RB2/IL-23R，IL-10などが同定され大きく疾患 理解が進んでいる. 一方でぶどう膜炎の病因病態研究は動物疾患モデルを用いることで発展してきた. 特に眼局所抗原（網膜抗原）をマウスに免疫することで誘導される実験的自己免疫性ぶどう膜網膜炎 (EAU) では Th1, Th17, Th22 などの抗原特異的な effector T 細胞が作用することによりぶどう膜網 膜炎が発症する. EAU は病理組織学的にもヒトぶどう膜炎と類似点も多くべーチェット病ぶどう膜網 膜炎の新規治療法の開発, 安全性の評価などに重要なツールである. 本ワークショップでは免疫恒常性 の維持に必須な役割を果たす Foxp3+ 制御性 T 細胞に注目し, IL-2 を介した制御性 T 細胞による EAU の炎症抑制機構を中心に報告する.

\section{慶野 博先生 ご略歴}

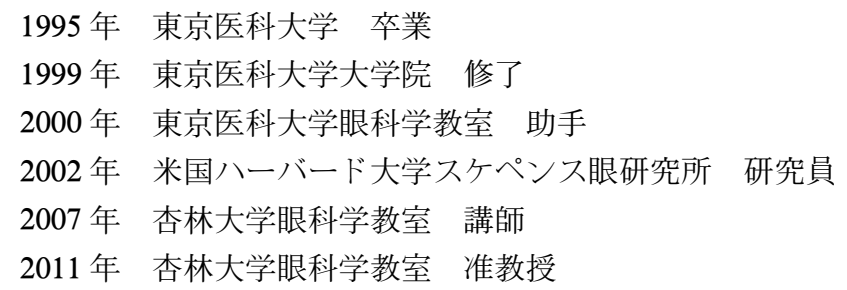

